\title{
DIE OMVANG EN AARD VAN AFWESIGHEID IN DIE WERKPLEK: 'N SUID-AFRIKAANSE GEVALSTUDIE
}

\author{
ANEL DU PLESSIS \\ DELÉNE VISSER \\ LINDA FOURIE \\ Program in Bedryfsielkunde \\ Department Menslikehulpbronbestuur \\ Randse Afrikaanse Universiteit
}

\begin{abstract}
The scope and nature of absenteeism in the workplace: A South African case study. The objective of the study was to develop quantitative measures for monitoring trends of absenteeism in a company within the meat industry and to assess qualitatively the possible existence of a collective culture of absenteeism within the organisation. The scope and frequency of absenteeism, costs incurred due to absenteeism, and individual absenteeism patterns of 145 employees, were studied over a period of one year. It was found that 2900 planned and 912 unplanned leave workdays that were lost, resulted in direct costs of R895,054.55. Five employees who were absent most often accounted for $18.60 \%$ of the unplanned leave taken. The extraordinary levels of absenteeism found in this case study were ascribed to specific employees
\end{abstract}

\section{OPSOMMING}

Die doel van die studie was om kwantitatiewe metings vir die monitering van afwesigheidstendense vir ' $n$ maatskappy in die vleisbedryf te ontwikkel en om die moontlike bestaan van ' $n$ kollektiewe afwesigheidskultuur kwalitatief te ondersoek. Die omvang, frekwensie en koste van afwesigheid, asook individuele afwesigheidspatrone, is bestudeer vir 145 werknemers oor ' $n$ tydperk van een jaar. Daar is bevind dat 2900 beplande en 912 onbeplande verlofwerkdae wat verloor is, die maatskappy R895,054.55 gekos het. Vyf werknemers wat die meeste afwesig was, was verantwoordelik vir $18,60 \%$ van die onbeplande verlof geneem. Die uitsonderlike vlakke van afwesigheid in hierdie gevalstudie is toegeskryf aan spesifieke werknemers.

\section{SYNOPSIS}

Absenteeism in the workplace is a phenomenon that is receiving increasing attention due to its cost implications. Companies in South Africa are taking a closer look at the costs of absenteeism and are, by implication, addressing issues such as employee loyalty and commitment. The present study focused on the nature and extent of absenteeism in a company in the meat industry, the total number of productive days lost by the company, the mean duration of absenteeism incidences, and the costs incurred. The possibility of a collective culture of absenteeism was also investigated by studying individual absenteeism patterns.

Attendance records of 145 employees over a period of one year were studied. The leave records included annual leave, sick leave, leave without permission and compassionate leave. Annual vacation leave was defined as planned leave, whereas sick leave, leave without permission and compassionate leave were defined as unplanned leave. In the case of unplanned leave, costs were inevitably incurred to employ temporary workers to maintain production levels, because the processing of fresh meat cannot be delayed. Altogether 2900 workdays were lost due to planned leave and 912 workdays were lost due to unplanned leave. This meant that 24 percent of all absenteeism was due to unplanned leave, whereas 76 percent consisted of planned leave.

The costs of absenteeism were calculated by totalling the number of workdays (planned and unplanned) lost due to absenteeism. This amounted to a total of 3812 days, which resulted in a loss of R485,644.31 (including company contributions). The cost incurred to employ temporary workers to accommodate absenteeism amounted to R409,410.24 over a period of one year. The total cost of absenteeism was thus R895,054.55. This figure does not include indirect costs due to the loss of quality from using temporary workers nor costs due to supervisory time spent to reorganise the different departments.

Versoeke vir afskrifte moet gerig word aan: D Visser, Departement

Menslikehulpbronbestuur, RAU Universiteit, Posbus 524, Auckland Park, 2006
It was also investigated whether factors such as years of service, age, educational level, or job level influenced absenteeism. Only in the case of job level a statistically significant correlation with number of days absent was obtained.

The possibility of the existence of a collective culture of absenteeism was researched. This was done by studying the absenteeism patterns of the five employees who took the largest number of unplanned leave days and that of the five employees who most often took periods of leave. All of these employees worked in one particular department. Although they constituted only 3.45 percent of the total sample, they accounted for $18.60 \%$ of the unplanned leave taken by the weekly-paid employees.

The conclusion reached is that absenteeism can amount to extremely high levels of unplanned costs for companies, possibly higher than companies are generally aware of. Unless efforts are made to calculate the exact costs of absenteeism, the extent thereof usually remains hidden. In the present research a detailed example of how absenteeism may be studied, was shown. The exorbitant levels of absenteeism found in one department only, raised the suspicion that this was due to a collective culture of absenteeism in that particular department, but this hypothesis was not supported. The fact that a small number of individuals can dramatically influence the overall absenteeism pattern of a company, raises the concern that such employees may eventually also affect the work values and commitment of other employees.

Afwesigheid in die werkplek is ' $\mathrm{n}$ verskynsel wat arbeidsproduktiwiteit op verskillende wyses nadelig beïnvloed. Die voor-diehand-liggendste negatiewe gevolge sluit die verlies aan produksietyd, verlaagde produktiwiteit, verswakte kwaliteit en moreelprobleme by personeel in (Fletcher, 2000). Die probleme wat afwesigheid skep, bied 'n geleentheid om die redes daarvoor te ondersoek en oplossings te vind (Kelly, 1992). Daar kan dus gepoog word om die verskynsel van afwesigheid in die werkplek te verstaan sodat gepaste bestuursmaatreëls getref kan word om die ontwrigtende en ongewenste impak daarvan te beperk. 
Die diverse aard van die werkmag in Suid-Afrika skep probleme van sy eie (Martocchio, 1994). Onkundigheid betreffende die motiewe onderliggend aan die verskynsel van ongewenste afwesigheid in die werkplek bring werkgewers telkens voor die 'andersheid' en ontwrigting wat afwesigheid meebring, te staan. Daarbenewens speel die verskynsel van afwesigheid in SuidAfrika hom af teen ' $\mathrm{n}$ agtergrond van verswakte produktiwiteit en ' $\mathrm{n}$ onwilligheid aan die kant van die werknemer om verantwoordelikheid of eienaarskap van sy eie optrede te aanvaar (Buschak \& Craven, 1996). Belangstelling in die verskynsel van afwesigheid is deels te verklaar deur die toenemende noodsaaklikheid vir ondernemings om hul eie produktiwiteit voortdurend met dié van hulle mededingers in die mark te vergelyk. Ten spyte van die feit dat afwesigheid in die werkplek ' $n$ wêreldwye verskynsel is, is die situasie in Suid-Afrika van besondere belang, veral weens die negatiewe persepsie wat ten aansien van algemene produktiwiteitsindekse in Suid-Afrikaanse ondernemings bestaan.

Alhoewel aanvaar word dat ' $\mathrm{n}$ doeltreffende verlofstelsel binne ondernemings voordele vir sowel die werkgewer as die werknemer inhou, spreek dit vanself dat ondernemings sal poog om ongewenste en onbillike afwesigheid te minimaliseer en bywoning te maksimaliseer. Die vraag onstaan egter hoe daar sinvol tussen gewenste en ongewenste, of andersins, billike en onbillike afwesigheid in die werkplek onderskei kan word. Maatstawwe of parameters aan die hand waarvan afwesigheid kwantitatief, maar waarskynlik ook kwalitatief, beoordeel sou kon word, is dus wenslik. Terwyl ondernemings nie sou wou poog om afwesigheid in die werkplek totaal te verhoed nie, sou hulle uiteraard wou poog om billike en behoorlike afwesigheid toe te laat en sodanig te bestuur dat die minste ontwrigting daardeur teweeg gebring word en om onbillike en onbehoorlike afwesigheid te verhoed of tot die minimum te beperk.

Die literatuur verskaf enkele riglyne aan die hand waarvan afwesigheid geklassifiseer of gekategoriseer kan word. De Villiers (1992) het afwesigheid beskryf as die nie-bywoning van werk as gevolg van redes buite die werknemer en werkgewer se beheer. Koslowsky, Sagie, Krausz en Singer (1997) se siening was anders, naamlik dat afwesigheid beskou word as die onttrekking van ' $n$ werknemer weens onvoorsiene omstandighede of doelbewuste georkestreerde situasies. Volgens hierdie beskouing word beplande jaarlikse vakansieverlof nie as afwesigheid beskou nie, alhoewel siekteverlof en verlof sonder toestemming wel as afwesigheid geklassifiseer sou kon word.

In die praktyk word die volgende vier verlofkategorieë dikwels binne (Suid-Afrikaanse) ondernemings aangetref: Jaarlikse vakansieverlof, siekteverlof, geleentheidsverlof en verlof sonder toestemming. Vir die doeleindes van hierdie studie blyk dit wenslik om die verskillende kategorieë verlof soos volg te definieer:

\section{- Beplande afwesigheid}

Dit is afwesigheid wat deel vorm van die werknemer se dienskontrak, wat duidelik gekwantifiseer is en volgens vaste reëls gereguleer en beplan word. Slegs jaarlikse vakansieverlof word vir die doeleindes van hierdie studie as beplande verlof geklassifiseer.

Die voordele van beplande jaarlikse vakansieverlof vir sowel die werkgewer as die werknemer, is voor-die-hand-liggend. Mits die voorskrifte en vaste reëls verbonde aan die toestaan van jaarlikse verlof gevolg word, kan geredeneer word dat jaarlikse vakansieverlof gewenste, billike en behoorlike afwesigheid impliseer. 'n Werknemer wat tydens vakansieverlof na behore kan uitrus, het waarskynlik eerder die geleentheid om na sy normale pligte terug te keer as ' $n$ werknemer vir wie daar nooit behoorlike rustye toegelaat sou word nie.

- Onbeplande afwesigheid

Dit is afwesigheid waarvoor daar gedeeltelik in ' $n$ werknemer se dienskontrak voorsiening gemaak word. Hierdie afwesigheid is slegs gedeeltelik gekwantifiseer en is grootliks binne die diskresionêre aanwending van die werknemer, maar is buite die beheer en beplanning van die werkgewer. Siekteverlof, geleentheidsverlof en verlof sonder toestemming word vir die doeleindes van hierdie studie as onbeplande afwesigheid beskou. Dikwels kom hierdie afwesigheid op kort kennisgewing voor, met 'n gepaargaande ontwrigting waarvoor die werkgewer nie kon voorberei nie. Die omvang, frekwensie en duur van afwesigheid val ook nie binne die beheer en beplanning van die werkgewer nie en die moontlikheid vir misbruik aan die kant van die werknemer is uiteraard groter.

Die wenslikheid van gepaste siekteverlof is nie te betwyfel nie. ' $\mathrm{n}$ Ongestelde werknemer skep nie alleen gesondheids- en veiligheidsrisiko's vir homself nie, want die gesondheid en veiligheid van ander werknemers word ook in gedrang gebring. Gepaste siekteverlof sou dus in die reël as gewens en billik beskou kon word. Die feit dat die omvang, frekwensie en duur van afwesigheid weens siekte egter dikwels binne die beheer van die werknemer val, skep groter geleentheid vir wanaanwending. Dit is nie onmoontlik dat siekteverlof in so ' $n$ mate deur ' $n$ werknemer misbruik kan word dat dit uiteindelik tot dissiplinêre optrede of selfs ontslag kan lei nie. Net soos in die geval van siekteverlof, kan die toestaan van gepaste geleentheidsverlof dikwels as gewens en billik beskou word. Gehalte-van-lewe oorwegings en 'n humanitêre houding jeens werknemers in moderne ondernemings speel hier ' $\mathrm{n}$ sleutelrol. Dit word nie as onvanpas beskou om ' $n$ werknemer toe te laat om byvoorbeeld na die afsterwe van 'n geliefde, of die geboorte van 'n baba, 'n paar dae afwesig te wees nie. Die verwagting is dat so ' $\mathrm{n}$ werknemer in normale omstandighede meer geneë sal wees om goeie werk te lewer, omdat die onderneming ook op werknemers se persoonlike behoeftes ag slaan. Soortgelyk aan die situasie betreffende siekteverlof bestaan ruimte vir misbruik egter ook in ' $n$ mate. Dit spreek vanself dat die werkgewer die vergunning van geleentheidsverlof noukeurig behoort te monitor en bestuur.

Afwesigheid sonder toestemming is ' $\mathrm{n}$ verskynsel wat om ooglopende redes, slegs by absolute uitsondering as aanvaarbaar en billik beskou kan word. Soms mag regmatige verskonings soos vervoerprobleme of siekte in ' $n$ besondere geval bestaan (Kelly, 1992). Nogtans skep die ongewenstheid en ontwrigting van ongemagtigde afwesigheid ernstige probleme en spreek dit vanself dat ondernemings die verskynsel tot die minimum sal wil beperk en waar nodig, met drastiese stappe sal bestry. Die moontlikheid van dissiplinêre optrede of selfs ontslag sal waarskynlik nie uitgesluit word nie.

' $\mathrm{n}$ Behoorlike klassifisering of kategorisering van verlof is egter nie genoegsaam om ' $n$ oordeel te fel oor die gewenstheid, billikheid of behoorlikheid van ' $n$ bepaalde werknemer (of groep werknemers) se afwesigheidspatroon oor 'n tydperk nie. Die literatuur verskaf min riglyne aan die hand waarvan gewenste, billike en behoorlike afwesigheidspatrone van minder gewenste, minder billike en minder behoorlike patrone onderskei kan word. Alhoewel die literatuur dui op die omvang van en gepaardgaande probleme verbonde aan afwesigheid in die werkplek, is dit dikwels nodig dat die menslikehulpbronpaktisyn, aan die hand van selfgekose parameters, oordele betreffende die omvang en aard van afwesigheid binne die werkplek moet fel.

Enkele maatstawwe/parameters aan die hand waarvan die omvang van afwesigheid in die werkplek gekwantifiseer kan word, word in die literatuur vermeld.

- Verlore tyd word dikwels uitgedruk as die getal dae wat 'n werknemer afwesig is (Goldberg \& Waldman, 2000). Hierdie maatstaf dui ooglopend op die omvang van die verskynsel van afwesigheid binne die betrokke omgewing.

- Die koste van afwesigheid sou moontlik as 'n verdere maatstaf van afwesigheid aangewend kon word. Cascio (1991) het ' $n$ metode beskryf waarvolgens die direkte salaris/loonkoste 
verbonde aan afwesigheid in die werkplek bereken kan word. Daar moet egter in gedagte gehou word dat ' $n$ ontleding van direkte salaris/loonkoste nie noodwendig ' $n$ volledige weergawe van die koste van afwesigheid daarstel nie. Etlike ander kostes, hetsy direk of indirek, is ook betrokke. In hierdie verband kan onder meer verwys word na die direkte kostes om tydelike vervangende werknemers aan te stel, om werk te herorganiseer of om verlore werk in te haal (Cascio, 1991; Fletcher, 2000; McKee, 1992). Daarbenewens is indirekte kostes soos die kostes verbonde aan die verlaagde moreel onder werknemers, verswakte produktiwiteit, verlies aan kwaliteit, toename van frustrasie by bestuur en ongerief en ongelukkigheid by werknemers ook ter sprake (Cascio, 1991; Fletcher, 2000; McKee, 1992).

- Goldberg en Waldman (2000) het op hulle beurt verwys na 'n derde maatstaf van afwesigheid, die frekwensie van afwesigheid, of die aantal geleenthede wat ' $n$ werknemer binne ' $n$ bepaalde periode van die werk afwesig was.

- 'n Vierde moontlike maatstaf van afwesigheid is deur Chadwick-Jones, Nicholson en Brown (1982) vermeld waarvolgens die (tyds)duur van afwesigheid ook in die ontleding van afwesigheid in die werkplek aangewend sou kon word.

Al die voormelde maatstawwe van afwesigheid behels kwantitatiewe ontledings, maar dit spreek vanself dat navorsers op kwalitatiewe wyse sal moet oordeel of die omvang, frekwensie of duur van 'n werknemer (of groep werknemers) se afwesigheid binne ' $n$ bepaalde tydperk - gegewe die geldende omstandighede - gewenste, billike en behoorlike gebruik van verlofvoorsiening behels, al dan nie.

Wat die aard van afwesigheid in die werkplek betref, verskaf die literatuur ' $n$ komplekse prentjie wat daarop dui dat afwesigheid 'n multidimensionele verskynsel is.

- Afwesigheid het ' $n$ individuele dimensie wat impliseer dat individuele eienskappe soos pligsgetrouheid, lojaliteit en werknemertevredenheid ' $n$ werknemer se afwesigheidspatrone mag beïnvloed (Goldberg, 1990). So byvoorbeeld sal pligsgetroue of lojale werknemers minder geneig wees tot afwesigheid en sal ekstroverte werknemers in dieselfde omstandighede, meer geneig wees tot afwesigheid as introverte werknemers. Sagie (1998) het die verband tussen pligsbesef en lojaliteit, werknemertevredenheid en die intensie om op te hou werk aan die een kant, en afwesigheid aan die ander kant bevestig. Verdere veranderlikes soos ' $n$ werknemer se eksterne verantwoordelikhede en persoonlike motivering en vermoë om by te woon, speel moontlik ook ' $\mathrm{n}$ rol (Steer \& Rhodes, 1984). Daarbenewens het Porter en Steers (1973) bevind dat werknemers met ekstreme vlakke van emosionele onstabiliteit, angstigheid, aggressie, onafhanklikheid en selfvertroue meer geneig is tot afwesigheid as werknemers met meer gematigde persoonlikheidseienskappe. Verdere bevindings dui daarop dat ' $n$ individu se eie siening van die belangrikheid van aanwesigheid, afwesigheid wesenlik beinvloed en dat ' $n$ geskiedenis van afwesigheid positief verband hou met huidige afwesigheidspatrone (Garrison \& Muchinsky, 1977; Landy, Vasey \& Smith, 1984). Hiervolgens is dit te verwagte dat werknemers met ' $\mathrm{n}$ geskiedenis van afwesigheid nie sal skroom om met hierdie gedrag voort te gaan nie.

- Afgesien van ' $n$ individuele dimensie het afwesigheid klaarblyklik ook ' $n$ organisatoriese/werkgroep dimensie wat impliseer dat organisatoriese of groepdinamika soos organisasiewaardes, dissipline en toesighouerondersteuning, afwesigheidspatrone mag beïnvloed (Buschak \& Craven, 1996; Deery, Erwin, Iverson \& Ambrose, 1995). Verskeie faktore soos swak moreel, konflik, onvoldoende opleiding, onveilige werksomstandighede asook bepaalde houdings - eerder as werklike gedrag, kan eweneens met afwesigheid verbind word (Iverson, Olekalns \& Erwin, 1998). Aspekte soos die roetinering van werk en geakkumuleerde siekteverlofvoorsiening (Steer \& Rhodes, 1984) kan ook 'n rol speel.
Mastekaase en Olsen (1998) het na verhoogde arbeidsomset verwys as ' $\mathrm{n}$ verdere organisatoriese veranderlike wat met verhoogde afwesigheid onder werknemers verband mag hou. Buschak en Craven (1996) het bevind dat afwesigheid in ' $\mathrm{n}$ vervaardigingsonderneming hoër is as in ' $n$ korporatiewe omgewing en terselfdertyd ook hoër is in werksomgewings waar unieverteenwoordiging aanwesig is. Giraud (1987) se navorsing het getoon dat werknemers in poste wat lae vlakke van vaardighede vereis, geneig is om meer afwesig te wees as werknemers van wie hoër vaardighede vereis word. ' $n$ Verdere organisatoriese aspek wat 'n rol mag speel, is die verhouding tussen diskresie en dissipline, wat op verskillende vlakke van die onderneming en ten opsigte van verskillende kategorieë werknemers verskillend mag manifesteer. So byvoorbeeld het Cheng (1984) bevind dat werknemers wat meer lojaal is, afwesigheid volgens eie diskresie beperk, terwyl werknemers wat minder lojaal is, eerder op dissipline reageer. Van Yperen, Hagedoorn en Geurts (1996) het die belangrikheid van lojaliteit as ' $n$ bepaler van ' $n$ individu se werkbetrokkenheid bevestig en gedui op die waarde van 'n organisasieklimaat waarbinne 'n onderlinge afhanklikheidsgevoel tussen werknemers gevestig word en elke individu sy rol, bydrae en invloed begryp.

- Afwesigheid het klaarblyklik ook ' $\mathrm{n}$ sosiaal-maatskaplike dimensie wat impliseer dat gemeenskapwaardes en tersaaklike wetgewing ook ' $\mathrm{n}$ invloed op afwesigheidspatrone mag uitoefen. So byvoorbeeld hou persepsies van tyd belangrike implikasies vir ' $n$ persoon se emosie, kognisie en motivering in wat uiteraard op hulle beurt afwesigheidstendense positief of negatief kan beïnvloed (Carstensen, Isaacowitz \& Charles, 1999). Volgens hierdie navorsers sal die tydsgrense wat kollektief aan ' $n$ individu oorgedra word, 'n raamwerk skep waarbinne die individu sy eie doelwitte (byvoorbeeld ten opsigte van werkbywoning of nie-bywoning) sal formuleer. Die rol van die gemeenskap en die houding van die regering teenoor aspekte soos persoonlike welvaart speel ook ' $\mathrm{n}$ rol. Dit mag gebeur dat kollektiewe afwesigheid die gevolg is van 'n regering se oproep tot kollektiewe eenheid en ekstreme vlakke van kollektiewe afwesigheid kan teen hierdie agtergrond dikwels beter verstaan en bestuur word (Kaiser, 1998).

' $\mathrm{n}$ Verskynsel wat dikwels in die literatuur vermeld word, is dié van die moontlike bestaan van ' $\mathrm{n}$ afwesigheidskultuur binne ' $\mathrm{n}$ bepaalde groep of omgewing (Chadwick-Jones, Nicholson \& Brown, 1982; Gellatly \& Luchak, 1998). Hiervolgens sou dit moontlik wees dat afwesigheid in ' $n$ besondere geval deur die heersende afwesigheidskultuur beinvloed mag word, aangesien 'n werknemer dikwels 'n normatiewe persepsie van die aanvaarbare afwesigheidspatrone binne die groep vorm. Dit mag implikasies inhou ten opsigte van die omvang, duur en frekwensie van afwesigheid binne die groep. Volgens Martocchio (1994) sal die individu se oortuiging of persepsie rakende die koste en gevolge van afwesigheid dikwels die basis van 'n afwesigheidskultuur vorm. Bydraend hiertoe is die geneigdheid van nuwe werknemers om die heersende organisasiewaardes, doelwitte en -standaarde, asook die groepwaardes, -norme en -standaarde aan te leer (Rousseau, 1985).

Gegewe die voorafgaande bespreking betreffende die komplekse aard van afwesigheid in die werkplek, kom dit voor of die sinvolle beheer en bestuur van afwesigheid moet begin met ' $\mathrm{n}$ deeglike kwantitatiewe en kwalitatiewe ontleding van bestaande afwesigheidspatrone. Slegs ' $n$ omvangryke kwantitatiewe en kwalitatiewe ontleding sou kon dui op moonlike individuele, groep-, organisasie-wye of ander kollektiewe tendense. Hierna sou dit moontlik wees om intervensies op die individuele, groepof organisasievlak te onderneem ten einde tendense te beheer en optimaal te bestuur.

Verskeie strategieë word voorgestel om afwesigheid te verminder. So byvoorbeeld kan die bestuursproses begin by die behoorlike kontrole van afwesigheid, die daarstel van ' $\mathrm{n}$ afwesigheidsbeleid 
geskoei op behoorlike leerbeginsels en die daarstel van bywoningsgeörienteerde ondernemingskulture (Bielous, 1993; Martocchio, 1994). Kelly (1992) het die wenslikheid beklemtoon van ' $n$ beleid wat die negatiewe gevolge van afwesigheid duidelik uitspel, terwyl die waarde van tydige korrektiewe aksies en toepaslike dissipline nie onderskat behoort te word nie. Mogae (1999) het gewys op die wenslikheid om werknemers geleidelik bewus te maak van die impak van afwesigheid op die winsgewendheid van die onderneming, terwyl Morgan (1999) 'n gemeenskaplike siening van produktiwiteit beklemtoon het, aangesien produktiwiteit vir verskillende individue en groepe verskillende betekenisse kan inhou. Dit is egter duidelik dat enige van die bogenoemde aksies slegs suksesvol uitgevoer kan word indien behoorlike bestuursinligting oor die omvang en die aard van afwesigheid beskikbaar is en bruikbare maatstawwe vir die evaluering daavan bestaan.

Die doel van die onderhawige studie sluit by hierdie siening betreffende die beheer en bestuur van afwesigheid in die werkplek aan en poog om ' $n$ metode te ontwikkel aan die hand waarvan sinvolle bestuursinligting rakende afwesigheid saamgestel en moontlike afwesigheidspatrone of tendense blootgelê sou kon word. In die eerste plek is die werklike afwesigheid binne die bepaalde werkomgewing behoorlik kwantitatief ontleed ten einde die omvang, koste, frekwensie en duur van afwesigheid in die verskillende verlofkategorieë te bepaal. Op grond van hierdie ontleding is indekse daargestel waarvolgens vergelykings tussen individuele werknemers en tussen verskillende werkgroepe getref kon word. In hierdie proses is ' $\mathrm{n}$ aantal newedoelstellings ook nagestreef, naamlik om te bepaal of afwesigheid betekenisvol beïnvloed is deur individuele veranderlikes soos ouderdom, opvoedkundige kwalifikasies en diensjare, organisatoriese veranderlikes soos afdeling en posvlak, en of daar, op grond van die bogenoemde ontledings, redes bestaan om 'n kollektiewe afwesigheidskultuur (moontlik in sommige afdelings of werkgroepe) te vermoed.

Daar is geen twyfel dat die doelmatige bestuur van afwesigheid in die werkplek verskeie voordele inhou nie. So byvoorbeeld lei programme om ongewenste afwesigheid te bekamp, dikwels tot aansienlike kostebesparings en dui die gepaardgaande intervensies soms op leemtes in die ondernemig se billike hantering van verlofkwessies (Moch \& Fitzgibbons, 1985). In die proses word die doeltreffendheid (of ondoeltreffendheid) van die werkmag dikwels blootgelê en kan regstellende stappe geneem word. Ook ten opsigte van die behoorlike bestuur van ' $\mathrm{n}$ onderneming se siekteverlofstelsels, kan etlike voordele vermeld word. Die impak van 'n werknemer se siektetoestand op ander werknemers kan nie onderskat word nie. Afgesien van die ooglopende gesondheidsrisiko's vir ander werknemers, ontstaan ander negatiewe gevolge dikwels. Gesonde werknemers kan ongelukkigheid ervaar, enersyds weens hulle eie verhoogde gesondheidsrisiko's (Lewis, 1997) maar andersyds ook weens die verhoogde werklading as gevolg van ' $n$ werknemer se afwesigheid. Die moontlikheid dat gesonde werknemers later self afwesig bly - uit weerwraak vir die ongerief en ontwrigting veroorsaak deur ander werknemers se afwesigheid, bestaan ook (Harrison \& Martocchio, 1998).

Verhoogde werkladings, 'n noodwendige gevolg van onbeplande en onbillike afwesigheid, word, afhangend van individuele werknemers se persoonlikhede, verskillend hanteer. Een moontlike gevolg is verhoogde alkoholgebruik wat op sigself tot verlaagde produktiwiteit en/of verdere siekteverlof of ander vorms van afwesigheid aanleiding kan gee (Kelly, 1993; Albertson, 1999). Volgens Jones, Casswell en Zhang (1995) neem afwesigheid weens alkoholmisbruik 'n geweldige omvang aan en lei die probleem tot verminderde produktiwiteit van soveel as $25 \%$ by gereelde alkoholgebruikers, selfs al is hulle by die werkplek aanwesig. Verdere ongewenste reaksies op verhoogde werkladings sluit byvoorbeeld versteurde slaappatrone en probleme met ontspanning in (Kelly, 1993). Die omvang van die nadelige gevolge verbonde aan (ongewenste) afwesigheid in die werkplek is omvangryk en vir dié rede is verdere navorsing in hierdie verband van betekenisvolle belang.

Die doelstellings van hierdie ondersoek kan gevolglik soos volg geformuleer word:

- Om aan die hand van 'n Suid-Afrikaanse gevalstudie 'n ondersoek na die omvang en aard van afwesigheid te onderneem ten einde kwantitatiewe maatstawwe vir die vergelyking van afwesigheidstendense te bepaal, en

- Om afwesigheidspatrone kwalitatief te bestudeer ten einde die moontlike bestaan van ' $n$ kollektiewe afwesigheidskultuur binne die onderneming te ondersoek.

\section{METODE}

\section{Respondente}

Die studie is onderneem in ' $n$ maatskappy in die vleisbedryf wat fokus op daaglikse voorsiening aan sy onderskeie fabrieke. Daar is besluit om te fokus op weekliksbesoldigde werknemers, omdat hulle ' $n$ homogene groep is en die meerderheid van die werknemers insluit. Indien 'n verskeidenheid posvlakke ingesluit sou wees, sou hierdie faktor moontlik strengeling veroorsaak het. Volgens Buschak en Craven (1996) is afwesigheid hoog in 'n vervaardigingsomgewing waar daar vakunieverteenwoordiging is. Die respondente het dus bestaan uit 145 manlike weekliksbesoldigde werknemers in 'n vervaardigingsomgewing met $100 \%$ vakunieverteenwoordiging. Hulle was afkomstig uit verskeie departemente, naamlik ' $n$ abattoirdepartement $(N=43)$, groothandel/gehalteverpakking departement $(N=20)$, ingenieursdepartement $(N=8)$ en ontbeningsdepartement $(N=$ 74). Hierdie departemente is apart ontleed sodat afwesigheidstendense uitgelig kon word. 'n Personeelstruktuur van die hele maatskappy (Tabel 1) verskaf 'n uiteensetting van die samestelling van al die posvlakke binne die maatskappy. Alle personeel is op hierdie struktuur aangedui.

\section{Data-insamelingsprosedure}

Daar is gebruik gemaak van 'n gevestigde klokkaartstelsel en teenwoordigheidregisters wat die daaglikse administrasie van afwesigheid sorgvuldig monitor. Hierdie rekords verskaf geredelik beskikbare en bruikbare statistiek vir die vasstelling van afwesigheidtendense. Bestaande syfers is geverifieer met maandelikse gerapporteerde afwesigheidsyfers vanaf Junie 1999 tot Mei 2000. Daar is ook gebruik gemaak van syfers rakende die weeklikse rapportering van kostes om afwesige werknemers met tydelike werknemers te vervang.

Die data vir die studie is soos volg ingesamel. ' $\mathrm{n}$ Databasis wat alle biografiese data van die 145 werknemers bevat, is opgestel as basis vir verdere ontleding. Hierdie biografiese data sluit inligting soos die werknemer se posgradering, kloknommer, loon, diensjare, ouderdom, postitel, kwalifikasie, geslag en nasionaliteit in. Vervolgens is tydstate van die werknemers geneem oor ' $n$ tydperk van 12 maande (Junie 1999 - Mei 2000) en alle verlof is by die databasis ingesluit. Die verskillende verlofkategorieë van beplande verlof (jaarlikse vakansieverlof) en onbeplande verlof (siekteverlof, verlof sonder toestemming en verlof vir sosiale verantwoordelik-heid) is vir elkeen van die 145 werknemers aangeteken.

Ten einde die omvang van afwesigheid onder die weekliksbesoldigde werknemers te bestudeer, is die aantal dae afwesig en die koste van afwesigheid bereken soos hierna uiteengesit. Om die aard van afwesigheid onder weekliksbesoldigde werknemers te bestudeer, is die frekwensie en duur van verlofinsidente ondersoek. Hierna is die aard van afwesigheid verder bestudeer deur te fokus op afwesigheidspatrone van individue wat die meeste afwesig was. 
Aantal dae afwesig

In Tabel 2 word die omvang van afwesigheid uitgedruk in terme van dae. Die aantal dae in die onderskeie verlofkategorieë wat in die verskillende departemente geneem is, word verskaf. Dit is ook uitgedruk as ' $n$ persentasie van die totale aantal dae wat in daardie departement vir ' $n$ tydperk van een jaar gewerk is.

\section{Kosteberekening}

Die direkte koste van afwesigheid is bereken nadat die totale aantal dae verloor aan afwesigheid in die onderskeie departemente vasgestel is. Hierdie dae sluit beplande en onbeplande verlof in. Weekliksbesoldigde werknemers is verdeel in drie verskillende posvlakke/graderings (sien Tabel 3).

Die AA-vlak is die laagste besoldigde vlak (R477 per week). Hierdie werknemers se take vereis geen spesiale vaardighede nie.
Die AB-vlak (R489 per week) vereis van die werknemer om oor ' $n$ vaardigheid te beskik wat vir ' $n$ gespesialiseerde taak geskik is. Die AC-vlak (R513.50 per week) sluit werknemers in wat werk verrig wat klerklik van aard is.

Afwesigheidskoste per dag is bereken deur die vlak waarop die individu werksaam is, te gebruik om sy loon en maatskappybydraes te bereken. Werknemers se bruto loon per week sluit bydraes tot werkgewer fondse in en hoef dus nie apart verreken te word nie. Alle kostes wat die werkgewer aangaan is per dag bereken. Vir elke dag wat die werknemer dus afwesig was, is die totale koste vir daardie dag bereken.

Die eerste stap in die kosteberekeningoefening was om die werknemer se loon per dag te bereken. Dit is bereken deur die werknemer se loon per week (ongeag die vlak) te deel deur die

TABeL 1

Personeelstruktuur

\section{GESALARIEERDE WERKNEMERS}

\begin{tabular}{|c|c|c|c|c|c|c|}
\hline $\begin{array}{c}\text { Groothandel/ } \\
\text { Gehalteverpakking }\end{array}$ & $\begin{array}{l}\text { Tegnies/ } \\
\text { Kwaliteit }\end{array}$ & $\begin{array}{l}\text { Ingenieurs- } \\
\text { departement }\end{array}$ & Finansiële departement & $\begin{array}{l}\text { Ontbenings- } \\
\text { departement }\end{array}$ & Abattoirdepartement & $\begin{array}{c}\text { Menslike Hulpbron- } \\
\text { departement }\end{array}$ \\
\hline Bestuurder (x1) & Bestuurder (x1) & Bestuurder (x1) & Bestuurder (x1) & Bestuurder (x1) & Bestuurder (x1) & MH Beampte (x1) \\
\hline Produksie kontroleur (x1) & & Voorman (x1) & Assistent rekenmeester $(\mathrm{x} 1)$ & Klerk (x1) & Produksiekontroleerder $(\mathrm{x} 1)$ & Ontvangsdame $(\mathrm{x} 1)$ \\
\hline Toesighouers (x3) & & Elektrisiën (x1) & Debiteureklerk (x2) & Toesighouers (x3) & Vleisondersoekers (x4) & Klinieksuster (x1) \\
\hline \multirow[t]{2}{*}{ Administratiewe klerke (x2) } & & Passer (x2) & Krediteureklerk (x2) & & Toesighoeurs (x2) & Loonklerk (x1) \\
\hline & & Stoorman (x1) & & & Gradeerder (x1) & \\
\hline $\begin{array}{l}\text { Totaal } \\
(38)\end{array}$ & 1 & 6 & 6 & 5 & 9 & 4 \\
\hline \multicolumn{7}{|c|}{ WEEKLIKSBESOLDIGDE WERKNEMERS } \\
\hline $\begin{array}{c}\text { Groothandel/ } \\
\text { Gehalteverpakking }\end{array}$ & $\begin{array}{l}\text { Tegnies/ } \\
\text { Kwaliteit }\end{array}$ & $\begin{array}{l}\text { Ingenieurs- } \\
\text { departement }\end{array}$ & Finansiële departement & $\begin{array}{l}\text { Ontbenings- } \\
\text { departement }\end{array}$ & Abattoirdepartement & $\begin{array}{c}\text { Menslike Hulpbron- } \\
\text { departement }\end{array}$ \\
\hline Drywers (x2) - AC & Geen & Assistent stoorman (x1) - AC & Geen & Ontbeners $(\mathrm{x} 40)-\mathrm{AB}$ & Toesighouers(x1) - AC & Geen \\
\hline Varkvleisverpakkers (x9) - AB & & Drywers $(\mathrm{x} 1)-\mathrm{AC}$ & & Operateurs (x19) - AB & $\begin{array}{c}\text { Operateurs en } \\
\text { slagters(x23) - } \mathrm{AB}\end{array}$ & \\
\hline Laaiers (x9) - AA & & $\begin{array}{c}\text { Gereedskapassistent } \\
\text { (x6) - AB }\end{array}$ & & $\begin{array}{l}\text { Produkhanteerders } \\
\text { (x15) - AA }\end{array}$ & $\begin{array}{c}\text { Produkhanteerders, } \\
\text { skoonmakers (x19) - AA }\end{array}$ & \\
\hline $\begin{array}{l}\text { Totaal } \\
(145)\end{array}$ & 0 & 8 & 0 & 74 & 43 & 0 \\
\hline
\end{tabular}

TABEL 2

OMVANG VAN AFWESIGHEID UITGEDRUK IN TERME VAN DAE AFWESIG

\begin{tabular}{|c|c|c|c|c|c|c|c|c|c|c|}
\hline Dae & $\begin{array}{c}\text { Organisasie } \\
\text { Dae }\end{array}$ & $\%$ & $\begin{array}{l}\text { Abattoir } \\
\text { Dae }\end{array}$ & $\%$ & $\begin{array}{c}\text { Groothandel/Gehalteverpakking } \\
\text { Dae }\end{array}$ & $\%$ & $\begin{array}{l}\text { Ingenieurs } \\
\text { Dae }\end{array}$ & $\%$ & $\begin{array}{c}\text { Ontbening } \\
\text { Dae }\end{array}$ & $\%$ \\
\hline Totale aantal dae gewerk per jaar & $37,695.64$ & & $11,179.14$ & & $5,199.60$ & & $2,078.40$ & & $19,238.50$ & \\
\hline Jaarlikse verlof & 2900 & 7.7 & 860 & 7.7 & 400 & 7.7 & 160 & 7.7 & 1480 & 7.7 \\
\hline Siekteverlof & 613 & 1.6 & 153 & 1.4 & 44 & 0.8 & 26 & 1.3 & 390 & 2.0 \\
\hline Afwesigheid sonder toestemming & 263 & 0.7 & 4 & 0.0 & 16 & 0.3 & 0 & 0.0 & 243 & 1.3 \\
\hline $\begin{array}{c}\text { Sosiale } \\
\text { verantwoordelikheidsverlof }\end{array}$ & 36 & 0.1 & 4 & 0.0 & 7 & 0.1 & 5 & 0.2 & 20 & 0.1 \\
\hline TOTAAL & 3812.0 & 9.1 & 1021.0 & 9.1 & 467.0 & 9.0 & 191.0 & 9.2 & 2133.0 & 11.1 \\
\hline
\end{tabular}

TABel 3

SAMESTELLING VAN MAATSK APPYBYDRAES (DIREKTE KOSTE)

\begin{tabular}{|c|c|c|c|c|c|c|c|c|c|c|c|}
\hline Gradering & $\begin{array}{l}\text { Loon per } \\
\text { week }\end{array}$ & $\begin{array}{l}\text { Loon per } \\
\text { dag }\end{array}$ & $\begin{array}{c}\text { WVF per } \\
\text { dag }\end{array}$ & $\begin{array}{l}\text { Voorsorgfonds } \\
\text { per dag }\end{array}$ & $\begin{array}{c}\text { WCA } \\
\text { per dag }\end{array}$ & $\begin{array}{l}\text { Bonus } \\
\text { per dag }\end{array}$ & $\begin{array}{l}\text { Verlof } \\
\text { per dag }\end{array}$ & $\begin{array}{l}\text { Totale koste } \\
\text { per dag }\end{array}$ & $\begin{array}{l}\text { Totale aantal } \\
\text { werknemers per } \\
\text { gradering }\end{array}$ & $\begin{array}{c}\text { Totale koste } \\
\text { per werknemer } \\
\text { per jaar }\end{array}$ & $\begin{array}{c}\text { Totale koste } \\
\text { per jaar per } \\
\text { gradering }\end{array}$ \\
\hline & $\mathrm{R}$ & $\mathrm{R}$ & $\mathrm{R}$ & $\mathrm{R}$ & $\mathrm{R}$ & $\mathrm{R}$ & $\mathrm{R}$ & $\mathrm{R}$ & $\mathrm{R}$ & $\mathrm{R}$ & $\mathrm{R}$ \\
\hline AA & 477 & 95.40 & 1.10 & 11.35 & 2.01 & 7.95 & 7.22 & 125.03 & 43.00 & $32,507.54$ & $1,397,824.22$ \\
\hline $\mathrm{AB}$ & 489 & 97.80 & 1.13 & 11.64 & 2.01 & 8.15 & 7.40 & 128.13 & 97.00 & $33,313.54$ & $32,314,113.38$ \\
\hline \multirow[t]{2}{*}{$\mathrm{AC}$} & 513.5 & 102.70 & 1.19 & 12.22 & 2.01 & 8.56 & 7.78 & 134.46 & 5.00 & $34,959.34$ & $174,796.70$ \\
\hline & & & & & & & & & & TOTAAL & $\mathrm{R} 4,804,034.30$ \\
\hline
\end{tabular}


aantal werkdae in ' $n$ week (5). Publieke vakansiedae is nie ingereken nie.

Vervolgens is maatskappybydraes (direkte kostes) bereken:

Bydraes tot die werkloosheidsversekeringsfonds is ' $\mathrm{n}$ uitgawe wat deur die werknemer en die werkgewer aangegaan word. Die doel van hierdie fonds is om voorsiening te maak vir die werknemer indien hy afgelê of ontslaan word. Dit dien dus as ' $\mathrm{n}$ finansiële hulpmiddel terwyl die werknemer werkloos is. Die koste hiervan is soos volg bereken:

Gradering $A$ A. Werkgewerbydrae per maand $(\mathrm{R} 23.85) \div 4.333$ (aantal weke per maand) $\div 5$ (aantal werkdae per week). In die geval van graderings $A B$ en $A C$ was die werkgewerbydrae per maand R24.45 en R25.70 onderskeidelik.

Die volgende maatskappybydrae wat in berekening gebring is, was die werkgewer se bydrae tot die voorsorgfonds. In hierdie geval was die daaglikse bydraes soos volg:

Gradering AA. Werkgewerbydrae per maand (R246.05) $\div 4.333$ (aantal weke per maand) $\div 5$ (aantal werkdae per week). In die geval van graderings $A B$ en $A C$ is die werkgewerbydrae per maand R252.15 en R264.70 onderskeidelik.

Maatskappybydraes sluit ook die jaarlikse bydrae aan die ongevalle- of vergoedingskommissaris in. Die doel van hierdie bydrae is om voorsiening te maak vir kostes indien die werknemer ' $\mathrm{n}$ besering aan diens sou opdoen. Die vergoedingskommissaris ondersoek die ongeval en betaal dan die onkoste aangegaan deur die organisasie om na die werknemer se gesondheid om te sien tydens sy herstelperiode. Die berekening van hierdie kostes is gedoen deur die jaarlikse bydrae van die werkgewer aan die ongevallekommissaris (R104,487.72) deur 12 (maande) te deel. Hierdie is die bydrae per maand aan die ongevallekommissaris. Om die kostes per week te bepaal, is die bedrag per maand (R8707.31) verdeel deur 4.333 (aantal weke per maand). Die kostes per dag is verkry deur die antwoord (R2009.53) deur 5 (antal werksdae per week) te verdeel. Dit is die totale maatskappybydrae (R401.91) per dag. Aangesien die jaarlikse bydrae aan die ongevallekommissaris alle werknemers op die perseel insluit, moes die totale aantal werknemers (200) gedeel word in die koste per dag aan die ongevallekommissaris (R2). Dit verskaf die koste per werknemer per dag aan die ongevallekommissaris.

Die volgende kostes wat bereken is, is die werknemer se bonusvoorsiening (soos wat dit akkumuleer) per dag. Dit is bereken deur die weeklikse loon te vermenigvuldig met 4.333 (aantal weke per maand) $\div 12$ (aantal maande per jaar). Dit is die werknemer se bonus per maand. Om die waarde van die bonus per dag te kry, is die bonus per maand $\div 4.333$ (aantal weke per maand) $\div 5$ (aantal werksdae per week). Dit verteenwoordig die totale bedrag vir bonusvoorsiening per dag.

Werknemers is jaarliks geregtig op 20 dae vakansieverlof. Gevolglik moet die werkgewer finansiële voorsiening maak vir hierdie verlof. ' $n$ Verlofwaarde kan dus gekoppel word aan elke dag wat die werknemer afwesig is. Verlofkoste per dag is soos volg bereken: Weeklikse loon x 4.333 (aantal weke per maand) 22 (aantal werkdae per maand). Die antwoord is vermenigvuldig met 20 (aantal dae verlof waarop die werknemer geregtig is). Hierdie antwoord verteenwoordig die werknemer se verlofwaarde per jaar. Om hierdie waarde te herlei na koste per dag is die volgende berekening gedoen: Verlofwaarde per jaar $\div$ 12 (maande per jaar) $\div 4.333$ (aantal weke per maand) $\div 5$ (aantal werkdae per week). Vervolgens is die aantal werknemers per posgradering bepaal sodat die onderskeie kostes per posgradering per jaar vasgestel kon word. Die somtotaal van die totale koste per dag vir die onderskeie posgraderings verskaf dus 'n akkurate weergawe van die totale koste spandeer vir die werksmag per jaar.
Die kostes van afwesigheid is vir die 145 respondente afsonderlik oor 'n tydperk van 12 maande (Junie 1999 - Mei 2000) bereken (tabel beskikbaar op aanvraag).

Tydelike werknemers is in diens geneem met die oog op vervanging van afwesige werknemers of vakante poste weens ontslag (juis as gevolg van afwesigheid of ander verwante oortredings). Die koste van tydelike werknemers sluit alle voordele aan tydelike werknemers in soos byvoorbeeld oortyd, verlof, siekteverlof, WCA-koste (vergoedingskommissaris) en WVF (werkloosheidsver-sekeringsfonds). Die werklike koste van tydelike werknemers oor ' $\mathrm{n}$ tydperk van 12 maande (Junie 1999 - Mei 2000) word in Tabel 4 verskaf.

TABEL 4

KOSTE VAN TYDELIKE WERKNEMERS OM AFWESIGHEID TE AKKOMMODEER VIR DIE TYDPERK JUNIE 1999 TO MEI 2000

\begin{tabular}{ccc}
\hline Maand & Aantal tydelike werknemers & $\begin{array}{c}\text { Totale koste per maand } \\
\text { R }\end{array}$ \\
\hline Junie & 29 & $49,685.91$ \\
Julie & 23 & $39,086.14$ \\
Augustus & 25 & $49,384.55$ \\
September & 24 & $32,889.68$ \\
Oktober & 22 & $23,328.56$ \\
November & 11 & $21,979.53$ \\
Desember & 24 & $16,896.41$ \\
Januarie & 16 & $18,440.67$ \\
Februarie & 27 & $39,943.07$ \\
Maart & 26 & $32,639.03$ \\
April & 29 & $33,038.99$ \\
Mei & 31 & $52,097.71$ \\
TOTAAL & 287 & $409,410.25$ \\
\hline
\end{tabular}

Die omvang van afwesigheid in terme van die koste daarvan vir 'n tydperk van een jaar (Junie 1999 - Mei 2000), is bereken deur die totale koste van alle verlof geneem $(\mathrm{R} 485,644.31)$ by die totale koste van tydelike arbeid (R409,410.24) te tel. Die totale arbeidskoste van 145 werknemers is verder bereken (sien Tabel $3)$, waarna die persentasie afwesigheidskoste spandeer gesien kan word (sien Tabel 5).

TABel 5

OMVANG VAN AFWESIHEID IN TERME VAN KOSTE VIR DIE TYDPERK JUNIE 1999 - MEI 2000

Totale koste van alle verlof geneem (sien Tabel 2)

(beplande en onbeplande verlof)

Totale koste spandeer op tydelike arbeid om

afwesigheid te akkommodeer

TOTAAL

$\mathrm{R} 895,054.56$

Totale spandering aan 145 werknemers vir ' $\mathrm{n}$

tydperk van een jaar indien voorsiening gemaak

word vir maatskappybydraes en beplande verlof

(sien Tabel 3)

Persentasie koste van onbeplande afwesigheid

$18.6 \%$

Frekwensie van afwesigheid

Die aard van afwesigheid is bestudeer deur die gemiddelde frekwensie van alle verlofinsidente per werknemer te bepaal. Die frekwensie van afwesigheid dui dus die aantal geleenthede wat die werknemer verlof (beplan en onbeplan) geneem het, aan (sien Tabel 6). 
TABel 6

GEMIDDELDE FREKWENSIE EN DUUR VAN AFWESIGHEID

\begin{tabular}{|c|c|c|c|c|c|}
\hline & $\begin{array}{c}\text { Totale } \\
\text { werksmag }\end{array}$ & Abattoir & Ontbening & $\begin{array}{c}\text { Groothandel/ } \\
\text { Gehalteverpakking }\end{array}$ & Ingenieurs \\
\hline Aantal werknemers & 145 & 43 & 74 & 20 & 8 \\
\hline Gemiddelde frekwensie van jaarlikse verlof & 1.58 & 2.07 & 1.28 & 1.15 & 2.75 \\
\hline Gemiddelde duur van jaarlikse verlof & 16.4 & 13 & 17.88 & 18.45 & 15.13 \\
\hline Gemiddelde frekwensie van siekteverlof & 2.05 & 1.53 & 2.69 & 1.07 & 1.38 \\
\hline Gemiddelde duur van siekteverlof & 1.59 & 1.93 & 1.56 & 1.34 & 0.69 \\
\hline Gemiddelde frekwensie van afwesigheid sonder toestemming & 0.98 & 0.07 & 1.73 & 1 & 0 \\
\hline Gemiddelde duur van afwesigheid sonder toestemming & 0.78 & 0.09 & 1.37 & 0.72 & 0 \\
\hline Gemiddelde frekwensie van sosiale verantwoordelikheid & 0.12 & 0.05 & 0.15 & 0.27 & 0.3 \\
\hline Gemiddelde duur van sosiale verantwoordelikheid & 0.23 & 0.09 & 0.27 & 0.36 & 0.6 \\
\hline Totale gemiddelde frekwensie van beplande verlof & 1.58 & 2.07 & 1.28 & 1.15 & 2.75 \\
\hline Totale gemiddelde duur van beplande verlof & 16.4 & 13 & 17.88 & 18.45 & 15.13 \\
\hline Totale gemiddelde frekwensie van onbeplande verlof & 3.15 & 1.65 & 4.57 & 2.34 & 1.68 \\
\hline Totale gemiddelde duur van onbeplande verlof & 2.6 & 2.11 & 3.2 & 2.42 & 1.29 \\
\hline
\end{tabular}

\section{Duur van afwesigheid}

Die duur van verlofinsidente is ook ' $n$ maatstaf van die aard van afwesigheid. Die gemiddelde duur van verlof (beplan en onbeplan) geneem deur die werkemer dui op die aantal dae geneem per geleentheid/frekwensie. Hierdie inligting word ook in Tabel 6 verskaf.

\section{Individuele afwesigheidspatrone}

$\mathrm{Na}$ afloop van die bestudering van die omvang en aard van afwesigheid, is die afwesigheidspatroon van individue wat dikwels afwesig was, bestudeer. Die vyf werknemers wat die meeste aantal dae beplande en onbeplande verlof geneem het se afwesigheidspatrone is grafies voorgestel en die vyf werknemers met die hoogste frekwensie van afwesigheid (beplande en onbeplande verlof) is ook op hierdie wyse aangedui (Figure 1 en 2 is op aanvraag beskikbaar).

Figure 1 en 2 verskaf die aantal dae afwesig en frekwensie van afwesigheid onderskeidelik van die vyf werknemers met die hoogste vlakke van afwesigheid oor ' $n$ tydperk van 52 weke. Die figure bevat kleure en kon derhalwe nie gepubliseer word nie. Daar is aan elkeen van die vyf werknemers ' $n$ kleur toegeken en afwesigheid is aangedui in die vorm van een blokkie vir elke dag afwesig. Elke kolom dui ' $n$ week aan. Die blokkies wat geen kleur bevat nie, dui die verlof (beplan en onbeplan) van die orige 140 werknemers aan.

\section{RESULTATE}

Indien die resultate vir die omvang van afwesigheid (aantal dae afwesig en kosteberekening) beskou word, is 3812 dae verloor aan afwesigheid vir die totale groep respondente waarvan 2900 dae beplande en 912 dae onbeplande verlof was (sien Tabel 2). Die ontbeningsdepartement het $3.4 \%$ van die totale aantal werksdae afwesig afgestaan aan onbeplande verlof, terwyl die abattoirafdeling $1.4 \%$, die groothandel/gehalteverpakkingsdepartement $1.2 \%$ en die ingenieursdepartement $1.5 \%$ afgestaan het (sien Tabel 2). Die totale koste van beplande verlof was R369,479.10 en van onbeplande verlof R116,165.21 (tabelle beskikbaar op aanvraag). Die koste van tydelike werknemers oor 'n tydperk van 12 maande (Junie 1999 - Mei 2000) was R409,410.24 (sien Tabel 4). Die totale koste van beplande verlof, onbeplande verlof en die koste van tydelike werknemers was dus R895,054.55 (sien Tabel 5). Dit impliseer dat die gemiddelde koste van afwesigheid per werknemer R6172.79 wass. Die totale arbeidskoste spandeer om 'n soortgelyke werksmag vir 'n tydperk van een jaar in diens te neem, was $\mathrm{R} 4,804,034.30$ (sien Tabel 3). Die persentasie koste van alle afwesigheid was dus $18.6 \%$ (sien Tabel 5). Dit is verdeel in onbeplande verlof $(2.42 \%)$, beplande verlof (7.69\%) en tydelike arbeid (8.52\%).

Die resultate van die aard van afwesigheid (frekwensie en duur van afwesigheid) dui aan dat die ontbeningsdepartement die departement was met die hoogste gemiddelde frekwensie onbeplande verlof, met 'n gemiddelde van 4.57 geleenthede en 'n gemiddelde van 3.2 dae per geleentheid (sien Tabel 6).

Om te bepaal of daar verskille was ten opsigte van omvang en aard van afwesigheid tussen die onderskeie afdelings waarin die weekliksbesoldigde werknemers val, is statistiese hipotesetoetse uitgevoer. Die weekliksbesoldigde werknemers was afkomstig uit vier departemente. Drie van hierdie departemente was relatief groot, terwyl die vierde een (ingenieursdepartement) slegs agt werknemers ingesluit het. Omdat hierdie departement te klein was vir parametriese statistiese hipotesetoetsing moes besluit word of dit saam met een van die ander departemente gegroepeer kon word. Dit was egter nie wenslik nie, aangesien hierdie departement se funksies wesenlik verskil van die ander drie departemente. Die ingenieursdepartement is dus nie by die statistiese hipotesetoetse ingesluit nie.

TABEL 7

VERGELYKING VAN GEMIDDELDES VAN ONBEPLANDE VERLOF MET BETREKKING TOT GETAL DAE, FREKWENSIE EN DUUR

\begin{tabular}{|c|c|c|c|c|c|c|c|c|c|c|c|}
\hline \multirow[t]{2}{*}{ Verlofveranderlikes } & \multicolumn{2}{|c|}{$\begin{array}{l}\text { Ontbening } \\
(N=74)\end{array}$} & \multicolumn{2}{|c|}{$\begin{array}{l}\text { Abattoir } \\
(N=43)\end{array}$} & \multicolumn{2}{|c|}{$\begin{array}{l}\text { Groothandel/ } \\
\text { Woolworths } \\
(N=20)\end{array}$} & \multirow[b]{2}{*}{ Levene $F$} & \multirow[b]{2}{*}{$g v$} & \multirow[b]{2}{*}{$p$} & \multirow[b]{2}{*}{$\boldsymbol{F}$} & \multirow[b]{2}{*}{$p$} \\
\hline & $M$ & $S D$ & $M$ & $S D$ & $M$ & $S D$ & & & & & \\
\hline Getal dae & 2.96 & 3.19 & 1.25 & 1.31 & 1.12 & 1.22 & 7.30 & 2,133 & 0.001 & 8.38 & 0.000 \\
\hline Frekwensie & 1.52 & 1.54 & 0.55 & 0.55 & 0.58 & 0.58 & 9.80 & 2,134 & 0.001 & 11.03 & 0.000 \\
\hline Duur & 0.72 & 0.72 & 0.71 & 0.95 & 0.65 & 0.64 & 0.23 & 2,134 & 0.799 & 3.97 & 0.021 \\
\hline
\end{tabular}

Wilks se lambda $=0.83$

$\mathrm{F}(2,134)=4.35, \mathrm{p}=0.000$ 
TABel 8

PosT HOC-TOETSE OM VERSKILLE TUSSEN AFDELINGS TE IDENTIFISEER

\begin{tabular}{|c|c|c|c|c|c|c|}
\hline \multirow{2}{*}{$\begin{array}{l}\text { Verlofveranderliikes } \\
\text { Getal dae }\end{array}$} & \multirow{2}{*}{$\begin{array}{c}\text { Toets } \\
\text { Dunnett T3 }\end{array}$} & \multicolumn{2}{|c|}{ Afdeling } & \multirow{2}{*}{$\begin{array}{c}\text { Gemiddelde verskil } \\
-1.72\end{array}$} & \multirow{2}{*}{$\begin{array}{c}\text { Standaardfout } \\
0.48\end{array}$} & \multirow{2}{*}{$\frac{p}{0.000}$} \\
\hline & & Abattoir & Ontbening & & & \\
\hline & & Groothandel/WW & Ontbening & -1.85 & 0.63 & 0.000 \\
\hline & & Abattoir & Groothandel/WW & 0.13 & 0.68 & 0.972 \\
\hline \multirow[t]{3}{*}{ Frekwensie } & Dunnett T3 & Abattoir & Ontbening & -0.97 & 0.23 & 0.000 \\
\hline & & Groothandel/WW & Ontbening & -0.94 & 0.30 & 0.000 \\
\hline & & Abbatoir & Groothandel/WW & -0.03 & 0.32 & 0.995 \\
\hline \multirow[t]{3}{*}{ Duur } & Scheffè & Abattoir & Ontbening & -0.36 & 0.15 & 0.063 \\
\hline & & Groothandel/WW & Ontbening & -0.42 & 0.20 & 0.111 \\
\hline & & Abattoir & Groothandel/WW & 0.06 & 0.21 & 0.960 \\
\hline
\end{tabular}

Verskille tussen die departemente met betrekking tot onbeplande verlof is getoets deur 'n eenrigting MANOVA uit te voer. Vir hierdie omnibustoets is die tellings vir aantal dae afwesig, frekwensie van afwesigheid en duur van afwesigheid gebruik as die afhanklike veranderlikes. Die departement was die onafhanklike veranderlike. Die resultate van die MANOVA word in Tabel 7 gerapporteer.

Wilks se koëffisiënt lambda is gebruik om vas te stel of daar statisties beduidende verskille tussen die departemente is met betrekking tot onbeplande verlof. Die verkreë lambda van 0.83 $[F(6,133)=4.35, p<0.001]$ was statisties beduidend.

Eenrigtingvariansie-ontledings is hierna uitgevoer om moontlike verskille met betrekking tot aantal dae afwesig, frekwensie van afwesigheid en duur van afwesigheid vas te stel. Vir al drie afhanklike veranderlikes is beduidende verskille tussen die gemiddeldes van die departemente gevind. Statisties beduidende verskille is gevind tussen die variansies vir getal dae en frekwensie, maar nie vir duur van afwesigheid nie (Levene se toets). Laasgenoemde resultaat is in aanmerking geneem toe post hoctoetse onderneem is. Dunnett se T3-toets is vir getal dae en frekwensie gebruik, terwyl Scheffè se toets vir duur van afwesigheid gebruik is. Geen beduidende verskille ten opsigte van duur is tussen die departemente gevind nie. Vir getal dae het ontbening verskil van beide abattoir $(p<0.001)$ en groothandel/gehalteverpakking ( $p<0.001)$. 'n Soortgelyke resultaat is vir frekwensie gevind. Ontbening het weereens verskil van abattoir $(p<0.001)$ en groothande/ gehalteverpakking $(p<0.001)$. In elke geval was die tellings vir ontbening beduidend hoër as vir dié van die ander twee departemente. Die resultate van die post hoctoetse verskyn in Tabel 8.

'n Doelstelling van die ondersoek was om vas te stel of totale verlof geneem (beplande en onbeplande verlof) korreleer met ouderdom, diensjare, opvoedkundige kwalifikasie en posgradering. Die korrelasie van totale verlof met ouderdom en diensjare onderskeidelik, is bereken met die Pearson produkmomentkorrelasiekoëffisiënt, terwyl die korrelasie van totale verlof geneem met opvoedkundige kwalifikasie en posgradering bereken is met die Spearman rangordekorrelasiekoëffisiënt. Daar was geen beduidende korrelasies tussen die veranderlikes nie. Die resultate word in Tabel 9 aangebied.

Aangesien bogenoemde inligting die ontbeningsdepartement uitwys as die departement met die hoogste persentasie dae en frekwensie van afwesigheid, is daar besluit om die vyf werknemers uit die totale groep respondente (145) wat die meeste dae afwesig was (beplande en onbeplande verlof ingesluit) sowel as die vyf werknemers wat die hoogste frekwensie van afwesigheid openbaar het (beplande en onbeplande verlof ingesluit) nader te ondersoek.
TABel 9

\section{KORRELASIES TUSSEN INDIVIDUELE VERANDERLIKES} EN VERLOF GENEEM

\begin{tabular}{llr}
\hline & & Aantal dae verlof \\
\hline Diensjare & Pearson produkmomentkorrelasiekoëffisiënt & -0.080 \\
& $p$ (tweekantig) & 0.336 \\
& $N$ & 145 \\
\hline Ouderdom & Pearson produkmomentkorrelasiekoëffisiënt & -0.060 \\
& $p$ (tweekantig) & 0.503 \\
& $N$ & 145 \\
\hline Opvoedkundige & Spearman rangordekorrelasiekoëffisiënt & -0.130 \\
kwalifikasie & $p$ (tweekantig) & 0.131 \\
& $N$ & 145 \\
\hline Posgradering & Spearman rangordekorrelasiekoëffisiënt & 0.160 \\
& $p$ (tweekantig) & 0.062 \\
& $N$ & 145 \\
\hline
\end{tabular}

In Figuur 1 (beskikbaar op aanvraag) word data vir die vyf werknemers wat die meeste dae afwesig was, verskaf. Hierdie werknemers was almal afkomstig uit die ontbeningsdepartement. In die figuur word onderskei tussen beplande en onbeplande verlof waar elke werknemer deur ' $n$ eie kleur aangedui word. Beplande verlof is aangedui met ' $n$ patroon in die blokkie, terwyl onbeplande verlof slegs 'n kleur bevat. Die figuur dui die aantal dae geneem oor 'n tydperk van 52 weke aan, met die vyf onderskeie kloknommers in verskillende kleure.

Die koste van alle verlof (beplan en onbeplan) geneem deur hierdie vyf werknemers beloop R34,586.54 (tabel beskikbaar op aanvraag). Dit verteenwoordig $3.9 \%$ van die totale koste (insluitende tydelike arbeid) van afwesigheid van alle weekliksbesoldigde werknemers. Dit behels 274 onproduktiewe dae waarvan 100 dae beplande en 174 dae onbeplande verlof was. Die verlof wat deur hierdie vyf werknemers geneem is, verteenwoordig $7.19 \%$ van alle verlof geneem, beplan en onbeplan, deur die totale groep respondente.

In Figuur 2 (beskikbaar op aanvraag) word die vyf werknemers met die hoogste frekwensie afwesigheid aangedui. Die vyf werknemers met die hoogste frekwensie afwesigheid is ook afkomstig uit die ontbeningsdepartement. Opvallend uit hierdie data is dat drie van die vyf werknemers met die hoogste frekwensie dieselfde werknemers is met die meeste aantal dae afwesig (sien Figuur 1). Figuur 2 dui aan op hoeveel geleenthede hierdie vyf werknemers oor ' $n$ tydperk van ' $n$ jaar afwesig was. Dit is ook opvallend dat die aantal dae wat per geleentheid geneem is, van korte duur was. 


\section{BESPREKING}

Die doel van hierdie studie was om die omvang en aard van afwesigheid in die Suid-Afrikaanse werkomgewing te bestudeer. Die omvang van afwesigheid in hierdie gevalstudie is bestudeer deur eerstens die aantal dae van afwesigheid te bepaal en tweedens die berekening van die direkte koste van afwesigheid. Indien die aantal dae afwesig in aanmerking geneem word, toon die ontbeningsdepartement $3.4 \%$ afwesigheid in terme van onbeplande verlof (sien Tabel 2), terwyl onbeplande verlof in die ander drie departemente aansienlik minder was. Die koste verbonde aan beplande en onbeplande verlof (tabel beskikbaar op aanvraag), was R485,644.31; die koste van tydelike arbeid (sien Tabel 4) was R409,410.24; die totale arbeidskoste van 145 werknemers in diens vir 'n tydperk van een jaar (sien Tabel 3) was R4,804,034.30, wat die persentasie koste spandeer aan onbeplande afwesigheid op $18.6 \%$ te staan gebring het (sien Tabel 5). Dit beteken dat die organisasie $18.6 \%$ meer geld moes begroot om voorsiening te maak vir beplande verlof, onbeplande verlof en tydelike arbeid sodat afwesigheid geakkommodeer kan word. Die totale bedrag spandeer aan afwesigheid was R895,054.55 en bring die gemiddelde koste van afwesigheid per werknemer per jaar op R6172.79 te staan. Hierdie inligting kan as dien om in die toekoms rekening te hou met onbeplande verlof wanneer kosteberekeningoefeninge gedoen word vir die doeleindes van ' $n$ salarisbegroting. Die omvang van die behoefte aan tydelike arbeid word ook nie besef alvorens afwesigheid in werklikheid intree nie. Om hierdie rede kan die impak van hierdie bedrag op die begroting van enige organisasie lei tot grootskaalse onvoorsiene oorspandering.

Die aard van afwesigheid in hierdie gevalstudie is bestudeer deur die frekwensie en duur van afwesigheid in die onderskeie departemente te bepaal. Volgens Tabel 6 was die ontbeningsdepartement weer eens die departement met die hoogste gemiddelde frekwensie onbeplande verlof. As gevolg hiervan is die moontlikheid van ' $\mathrm{n}$ afwesigheidskultuur in hierdie departement en 'n onderlinge konflik tussen werknemers weens afwesigheid in gedagte gehou.

Die MANOVA wat uitgevoer is om verskille tussen aantal dae afwesig, frekwensie van afwesigheid en duur van afwesigheid vas te stel, was statisties beduidend (sien Tabel 7). Post hoctoetse het beduidende verskille aangedui vir die getal dae afwesig en die frekwensie daarvan. Daar was egter nie beduidende verskille vir die duur van afwesigheid nie (sien Tabel 8). Geen korrelasie is gevind tussen verlof geneem en individuele veranderlikes nie (sien Tabel 9). Hierdie statistiese ontledings dui daarop dat daar ' $n$ verband is tussen die getal dae wat die werknemer afwesig was en die frekwensie waarteen hierdie afwesigheid plaasgevind het. Dit het egter ook bevestig dat individuele veranderlikes soos ouderdom, diensjare en opvoedkundige kwalifikasies nie verband hou met afwesigheid nie. 'n Organisatoriese veranderlike, posvlak, hou ook geen verband met afwesigheid nie. Ekstreme vlakke van afwesigheid (veral onbeplande afwesigheid) is veral in een departement, naamlik die ontbeningsdepartement, gevind. Figure 1 en 2 dui daarop dat werknemers in beide gevalle afkomstig was uit die ontbeningsdepartement. Die koste spandeer aan verlof (beplan en onbeplan) vir die vyf werknemers met die meeste aantal dae afwesig verteenwoordig $7.12 \%$ van die totale koste van alle verlof. Hierdie vyf werknemers verteenwoordig $3.45 \%$ van die totale getal respondente. Dit beteken dat daar slegs sekere individue in die ontbeningsdepartement was wat tot 'n ekstreme mate afwesig was. Die hoë frekwensie van afwesigheid van die betrokke vyf werknemers (ook afkomstig uit die ontbeningsdepartement) sowel as die feit dat die aantal dae per geleentheid van korte duur was, dui aan dat daar uitsonderlike afwesigheidsvlakke onder die betrokke individue bestaan. 'n Moontlike rede vir hierdie gedrag is dat die onderskeie individue voel dat hulle te na gekom is deur ander werknemers se afwesigheid en dat hulle dan geregtig is op hulle beurt om afwesig te wees. Hierdie individuele vlak van oortuiging of persepsie van die individu, wat die basis vorm van 'n afwesigheidskultuur (Martocchio, 1994) kan as moontlike motivering dien vir die afwesigheidstendens in die ontbeningsdepartement alhoewel dit slegs sekere individue behels het.

Die bogenoemde inligting kan as genoegsame rede gesien word om daadwerklike stappe te neem in die bekamping van afwesigheid. Dit is belangrik vir die werknemer en werkgewer om te besef dat afwesigheid ' $\mathrm{n}$ tweeledige verantwoordelikheid is (Kelly, 1992). Die werknemer se verantwoordelikheid is om toe te sien dat daar voldoen word aan die redelike verwagtinge van die werkgewer deur aanwesig te wees. Die werkgewer se verantwoordelikheid berus in die skep van 'n werkomgewing wat bevorderlik is vir goeie bywoning. Werknemers is minder geneig om die organisasie te verlaat wanneer hulle meer betrokke voel in hul werk en dus oor die nodige lojaliteit beskik (Van Yperen, Hagedoorn \& Geurts, 1996). Daar moet dus 'n gevoel van waarde geskep word waarin die werknemer voel dat sy/haar bydrae benodig word deur die organisasie.

Dit is egter ook belangrik om nie indirekte koste uit die oog te verloor wanneer die totale koste van afwesigheid bereken word nie. Sommige onkostes is moeilik kwantifiseerbaar en kan nie noodwendig uitgedruk word in rande en sente nie (Fletcher, 2000). Kostes van afwesigheid wat vir die doeleindes van hierdie studie nie ingesluit is by die berekening van die totale koste van afwesigheid nie, is die volgende:

- Vaardigheidontwikkelingstoeslag - die organisasie spandeer hierdie koste globaal. Dit verteenwoordig ' $n$ persentasie van die betaalrol (wat dus die totale arbeidsmag van die organisasie insluit) en is eers sedert April 2000 in werking gestel.

- Streeksdiensteheffing - hierdie is ook 'n heffing wat maandeliks betaal word en word bepaal deur die totale aantal permanente werknemers in diens. Die koste word dus aangegaan ongeag of die werknemer aanwesig is of nie.

- Verlies aan tyd van toesighouers deur herverdeling van die departement as gevolg van afwesigheid. Toesighouers in hierdie konteks spandeer die minimum aantal tyd vir herorganisering as gevolg van die frekwensie van afwesigheid in die onderskeie departemente (veral die ontbeningsdepartement). Daar word dus nie veel produktiewe tyd verloor weens afwesigheid nie, aangesien die toesighouers die tempo beheer.

- Verlies aan kwaliteit van produk weens tydelike werknemers. Hierdie syfers is moeilik berekenbaar aangesien ' $n$ verlies aan kwaliteit nie noodwendig die verlies aan arbeid is nie, maar ook ander faktore insluit soos produksievereistes wat daagliks verander (Cascio, 1991).

Kostes soos beskermende klere, rookpouses, teetye en middagete is ingesluit by die berekening van die werknemer se daaglikse loon. Indien die werknemer dus nie aanwesig was nie, sluit die koste verloor vir daardie spesifieke dag ook bogenoemde kostes in. Die werkgewer skep dus vir die werknemer geleenthede vir die nodige onderbrekings, maar organisasies sal in die toekoms selfs nog meer kreatief moet wees in hul 'terug-werk-toe' benaderings. Die fokus sal op funksionaliteit moet wees en die vastelling van die werksmag se waarde (Kweller, 1998). Die omgewing wat geskep moet word, moet een wees waarin mense wil werk toe gaan.

Die bydrae van hierdie studie is tweeledig. Eerstens is die waarde geleë in 'n demonstrasie van hoe die teoretiese maatstawwe of parameters van afwesigheid aangewend kan word om die omvang en aard van afwesigheid in die werkplek te kwantifiseer. Tweedens is die waarde geleë in die demonstrasie van hoe kwantitatiewe maatstawwe of parameters van afwesigheid op ' $n$ praktiese vlak aangewend kan word om afwesigheidspatrone, soos die bestaan van ' $n$ afwesigheidskultuur, te identifiseer. Die veralgemeenbaarheid en nut van die bevindinge berus in die moontlikheid om die studie as ' $n$ basis van vergelyking vir 
soortgelyke ondersoeke te gebruik en om as riglyn te dien by die kwalitatiewe beskouing van behoorlike of onbehoorlike en billike of onbillike afwesigheidsgedrag binne die werkplek.

Slegs die aard en omvang van afwesigheid in die werkplek word in hierdie studie bespreek en is gebaseer op 'n Suid-Afrikaanse gevalstudie. Die oorsake van afwesigheidsgedrag is egter nie spesifiek nagevors nie. Die literatuur dui op verskeie moontlike oorsake vir afwesigheidsgedrag, maar verduidelik nie waarom dit op so ' $\mathrm{n}$ ekstreme wyse, soos gevind in die ontbeningsdepartement van die organisasie wat ondersoek is, manifesteer nie. Die impak van afwesigheid word egter onderskat en behoort meer aandag van bestuur te geniet (Cascio, 1991). Verdere navorsing behoort daarop te fokus om hierdie gedragspatrone te probeer verklaar en om ' $n$ volledige berekening van die koste (insluitend indirekte koste) van afwesigheid te maak. Indien sodanige inligting geredelik beskikbaar is vir bestuur, kan die aard en omvang van afwesigheid in die Suid-Afrikaanse werkomgewing gemonitor en meer doeltreffend beheer word.

\section{ERKENNING}

Die bystand van Riëtte Eiselen en die personeel van die Statistiese Konsultasiediens van RAU met die statistiese ontleding van die data, word met dank erken.

\section{VERWYSINGS}

Albertson, D. (1999). Always a story behind the numbers. Employee Benefit News, 13 (1), 9.

Bielous, G. (1993) August. Achieving acceptable employee attendance. Supervision, 68.

Buschak, M. \& Craven, C. (1996). Managing absenteeism for greater productivity. S.A.M. Advanced Management Journal, $61(1), 26$.

Carstensen, L.L , Isaacowitz, D.M. \& Charles, S.T. (1999). Taking time seriously: A theory of socioemotional selectivity. American Psychologist, 54, 165-181.

Cascio. W.F. (1991). Costing Human Resources: The financial impact of behaviour in organisations. Boston: PWS-Kent.

Chadwick-Jones, J.K., Nicholson, N. \& Brown, C. (1982). Social psychology of absenteeism. New York: Praeger.

Cheng, Y. (1994). Organisational commitment and job absenteeism: A study of British employees. International Sociological Association.

Deery, S.J., Erwin, P.J., Iverson, R.D. \& Ambrose, M.L. (1995). The determinants of absenteeism: Evidence from Australian bluecollar employees. International Journal of Human Resource Management, 6 (4), 825-848.

De Villiers, V. (1992). Afwesigheid van werk as verskynsel in die bedryf - 'n literatuurstudie. Ongepubliseerde magisterverhandeling, RAU.

Fletcher, L. (2000). Absence proves costly. Business Insurance, 34(27), 3.

Garrison, K.R. \& Muchinsky, P.M. (1977). Evaluating the concept of absence proneness. Personnel Psychology, 30, 389 -393.

Gellatly, I.R. \& Luchak, A.A. (1998). Personal and organisational determinants of perceived absence norms. Human Relations, $51(8), 1085$.

Giraud, C. (1987). Absenteeism, an organisational symptom: A sociological interpretation of a case study of administration at the regional level. Sociologie-du-Travalie, 29 (3), 323-337.

Goldberg, L.R. (1990). An alternative "description of personality": The Big-Five factor structure. Journal of Personality and Social Psychology, 59, 1216 - 1229.
Goldberg, C.B. \& Waldman, A. (2000). Modeling employee absenteeism: Testing alternative measures and mediated effects based on job satisfaction. Journal of Organisational Behaviour, 21, 665-676.

Harrison, D.A. \& Martocchio, J.J. (1998). Time for absenteeism: A 20-year review of origins, offshoots and outcomes. Journal of Management, 24 (3), 305.

Iverson, R.D., Olekalns, M. \& Erwin, P. (1998). Affectivity, organisational stressors, and absenteeism: A causal model of burnout and its consequences. Journal of Vocational Behaviour, 52, 1-23.

Jones, S., Casswell, S. \& Zhang, J.F. (1995). The economic costs of alcohol-related absenteeism and reduced productivity among the working population of New Zealand. Addiction, 90 (11), 1455-1461.

Kaiser, C.P. (1998). Dimensions of culture, distributive principles, and decommodification: Implications for employee absence behaviour. Journal of Sosio-Economics, 27 (5), 551.

Kelly, L. (1992). Attendance management: An issue of the '90s. Worklife Report, 8 (5), 12.

Kelly, L. (1993). Stressed out. Worklife Report, 9 (2), 18.

Koslowsky, M., Sagie, A., Krausz, M. \& Singer, A.D. (1997). Correlates of employee lateness: Some theroretical considerations. Journal of Applied Psychology, 82 (1), 79-88.

Kweller, D.S. (1998). The emerging model of absence management. HR Focus, 75 (8), 9.

Landy, F.J., Vasey, J.J. \& Smith, F.D. (1984). Methodological problems and strategies in predicting absence. In P.S. Goodman \& R.S. Atkin (Eds.), Absenteeism: New approaches to understanding, measuring, and managing employee absence. San Francisco: Jossey-Bass.

Lewis, D. (1997). Sick as a dog? Work can wait. Safety and Health, $155,72-73$.

Martocchio, J.J. (1994). The effects of absence culture on individual absence. Human Relations, 47 (3), $243-260$.

Mastekaase, A. \& Olsen, K. (1998). Gender, absenteeism, job characteristics: A fixed effects approach. Work and Occupations, 25 (2), 195-228.

McKee, B. (1992). The hidden costs of absenteeism. Nation's Business, 80, 10.

Moch, M.K. \& Fitzgibbons, D.E. (1985). The relationship between absenteeism and production efficiency: An empirical assessment. Journal of Occupational Psychology, 58 (1), 39-47.

Mogae, C. (1999) August. Untitled. Productivity, 9.

Morgan, P. (1999) August. The battle for capital. Unleash productive power. Productivity, 20.

Morgan, P. (1999) August. Productivity is everywhere. Productivity, 11.

Porter, L.W. \& Steers, R.M. (1973). Organizational, work and personal factors in employee turnover and absenteeism. Psychological Bulletin, 80, 151-176.

Rousseau, D.M. (1985). Issues of level in organizational research: Multi-level and cross-level perpectives. Research in Organisational Behaviour, 7, 1-37. Greenwich, CT: JAI Press.

Sagie, A. (1998). Employee absenteeism, organisational commitment, and job satisfaction: Another look. Journal of Vocational Behaviour, 52, 156-171.

Steer, R.M. \& Rhodes, S.R. (1984). Knowledge and speculation about absenteeism. In P.S. Goodman \& R.S. Atkins (Eds.). Absenteeism: New approaches to understanding, measuring, and managing employee absence. San Francisco: Jossey-Bass.

Van Yperen, N.W., Hagedoorn, M. \& Geurts, S.A.E. (1996). Intent to leave and absenteeism as reactions to perceived inequity: The role of psychological and social constraints. Journal of Occupational and Organisational Psychology, 63 (4), 367 